\title{
Rhetorical Moves in the Introductions of Islam-Related Research Articles
}

\author{
Tantry Ajeng Parnawati ${ }^{1)^{*}}$, Yazid Basthomi ${ }^{2)}$, Suharmanto Ruslan ${ }^{2)}$ \\ ${ }^{1)}$ English First-Sawojajar, Malang \\ ${ }^{2}$ English Language Teaching-Universitas Negeri Malang \\ Ruko WOW-Sawojajar Blok Tokyo 1/8, Jl. Raya Sawojajar, 65139. E-mail: tantry.ajeng.p@gmail.com*
}

\begin{abstract}
This study aims at investigating the rhetorical pattern of research articles introductions in Islam-related research articles published in Indonesia. The data of this study are taken from journals acredited by the Ministry of Research, Technology and Highest Education of Indonesia (Kemenristek Dikti) and analyzed by using Swales CARS (2004) model. The results reveal a different macro structure of research articles, variants of moves placement in the introduction, and the tendency of skipping M2 in the articles. Moreover, the research articles also employ paragraphs that do not belong to any moves in Swales CARS (2004) model.
\end{abstract}

Key Words: rhetorical pattern, research article, Swales CARS (2004) model

\begin{abstract}
Abstrak: Penelitian ini bertujuan untuk menyelidiki pola retorik dari bagian pendahuluan artikel penelitian terkait dengan Islam dalam jurnal yang dipublikasikan di Indonesia. Data dari penelitian ini diambil dari jurnal-jurnal yang diakreditasi oleh Kementrian Riset, Teknologi dan Pendidikan Tinggi Indonesia (Kemenristek Dikti) dan dianalisis menggunakan model Swales CARS (2004). Hasil penelitian mengungkap perbedaan pola utama dari artikel penelitian, varian penempatan langkah-langkah di bagian pendahuluan, dan kecenderungan untuk melewatkan M2 pada artikel-artikel tersebut. Artikel-artikel penelitian tersebut juga menggunakan paragraf-paragraf yang tidak termasuk dalam langkah-langkah model Swales CARS (2004).
\end{abstract}

Kata kunci: pola retorik, artikel penelitian, model Swales CARS (2004)

Among writing genres in academic community, a research article (RA) is considered as the most important genre (Fazilaftar and Naseri, 2014). Hence, studies in the area of RA, especially written by non-native speakers (NNS), have recently been a growing interest, which particularly concerns with the exploration of the textual organization or rhetorical patterns of RA.

The rhetorical patterns of RA have often been highlighted from one of the macro-structures of RA, either Abstract, Introduction, Method, or Discussion (Chahal, 2014) although there is a rhetorical study that examines RA regardless of the macro-structure (see Fazilaftar and Naseri, 2014). In view of the Introduction being crucial to lead readers to understand a study addressed, this present study explores the rhetorical pattern of research article introductions (RAIs) written by Indonesians writers.
Several studies in research article introductions (RAIs) have been conducted in various contexts, including the background of the writer as well as the field of study. With regard to the writer's background, there are a number of studies focusing on the difference of rhetorical moves in RAIs parts with particular concerns for Native Speaker (NS) and Non-Native Speaker (NNS) writers (see Khany \& Tazik, 2010; Sheldon, 2011; Agrawal 2015). There are also studies focusing on only NNS writing (see Ahamad \& Yusof ,2012; Safnil, 2013; Chahal, 2014; Suryani et. al, 2014); however, there seems to be a less number of studies focusing on only NS writing (see Samraj, 2002).

In terms of the field of study, there are different focuses of RAIs analysis with which researchers concern. Whereas there are studies examining Introduction of RA from across disciplines (see Samraj, 
2002; Safnil, 2013), some studies focus on only certain studies (see Ahamad\&Yusof, 2012; Chahal, 2014; Suryani, 2014)

The study by Samraj (2002) was conducted using a genre-based analysis between Wildlife Behaviors \& Conservations Biology written by NS. Using Swales CARS Model version 1990, Samraj (2002) found that Wildlife Behavior RAIs has less promotional function than Conversations Biology. Using a similar approach, Safnil (2013) examined RAIs from engineering science and medical sciences written by Indonesian academics. Employing Dudley Evans (1994) and Swales's model (1990), the study found that though the journals has been published internationally; they have not yet conformed to the rhetorical styles of RA by Native Speaker (NS). The only similarities between Indonesian writer and native writer are in term of territory establishment and niche occupying. Although one of these studies was conducted in Indonesia, all of these two studies used the old version of Swales CARS model version 1990.

Using the newest Swales CARS model version 2004, Suryani, et al (2014) examined five journals of Computer Science written by NSS from Malaysia. The study found that the majority of journals adopted Swales's model (2004) to construct the Introduction in RA. Thus, the model proposed by Swales (2004), CARS model, is considered suitable to identify rhetorical moves for NNS, in this case are Malaysian writers. Similarly, examining RAIs written by Malaysian, Ahamad \& Yusof (2012) put focus on Islamic studies field. However, they used Swales CARS model version 1990. In the study, they found that most of the introduction part of the articles contains the entire move of CARS model. But, there is little among the articles that follow CARS strictly. Even though the articles used CARS model, the organization of the model was arranged differently. Interestingly, using different model and different field of study, the introduction part of RA revealed different results. Thus, there should need another research concerning on the Swales Model version 2004 as the analytical tool for analysis RAIs.

Broadened to other fields of discipline, Basthomi (2006) and Anwar (2010) conducted research in the English Language Teaching (ELT) field, using different approaches. Basthomi (2006) focuses on Introduction of RAIs from verified journal by Direktorat Jenderal Pendidikan Tinggi Indonesia (DIKTI) that are written by Indonesian. Using content analysis approach, Basthomi (2006) found that rhetorical pattern of RAIs written by Indonesian writer is to some extent different with the broader context of international discourse community. Whilst Anwar (2010), the study used genre base approach. In addition, the focus is not only in Introduction part but also in Discussion part. Moreover, Anwar (2010) compared journals from for reputable journals of ELT that are written by NS and NNS. Besides concerning on rhetorical moves, Anwar (2010) also studied the intertextuality in each article. The study found that RAIs in three journals of language teaching employed Swales (1990) model consistently. However, both studies used old models of analysis proposed by Swales; CARS 1990.

Consequently, Research Article (RA) analysis particularly rhetorical analysis in Research Article Introductions (RAIs) has been improving. However, reckoning the importance of RA compare to the other kinds of academic writing, there should be more studies explore the other field of discipline. In the Indonesia context, there are already Research Article Introductions (RAIs) analysis in field of engineering science and medical science (see: Safnil, 2013), and ELT (see: Basthomi, 2006; Anwar, 2010). Most of them used the old version of Swales CARS Model version 1990. Therefore, this study will examine the Introductions part of RA from Religion studies journal using Swales CARS Model version 2004 which there is still no studies published in the Indonesia context so far. The Religion studies journal is selected since the fact that it has good accreditation by Kementerian Riset, Teknologi dan Pendidikan Tinggi Indonesia or the Ministry of Research, Technology and Highest Education of Indonesia (RISTEK DIKTI, in Indonesian term) and continuation in producing journal during the last six years.

\section{METHODS}

This study employs the qualitative research design because the main source of the data is taken from a journal that is clearly in form of written text. The data was taken from qualified journals that met the criteria set. The first criteria is the acreditation. The journals must be acredited by RISTEK DIKTI and of course the acreditation must be still valid until the current time. Second, the journals must be published in English. And the last, the journals must contain research article that present Introduction section. From the criteria set, there are three journals found. Each journal consists of different number of research articles. In total, there 
Table.1 Percentage of Move Placement Variants

\begin{tabular}{lccc}
\hline & Al-Jami'ah & JIS & IJIMS \\
\hline Standard placement & $50 \%$ & $30,8 \%$ & $57,1 \%$ \\
Non-standard placement & $11,1 \%$ & $23 \%$ & $14,3 \%$ \\
No M1 & $5,6 \%$ & - & $7,1 \%$ \\
No M2 & $22,2 \%$ & $38,5 \%$ & $7,1 \%$ \\
No M3 & $11,1 \%$ & - & $7,1 \%$ \\
No Moves & - & $7,7 \%$ & $7.1 \%$ \\
\hline
\end{tabular}

are 49 RAs that were selected as the source of data. The data was analyzed used Swales's CARS Model version 2004. In the model, the data was analyzed by identifying the use of phrase, clauses, sentences or paragraph that represents the moves and steps proposed by Swales CARS 2004 model. Knowing the moves and proposed 'meaning' of the phrase, clauses, sentences or paragraph in RAIs is important to value the quality of the writing and the communicative purpose of the article; meaning that RAIS written by Indonesian should meet the general rhetoric of RAIs or discourse community of RA as academic writing product.

\section{RESULTS}

\section{The Macro Structure of Research Articles in Islam Related Journal}

Macro structure or generic rhetorical structure is the sections presented in the research article. The study found another variant in the rhetorical structure of RAs in Islam Related journals that is different with the common macro structures found in genre analysis that is $\operatorname{IMRD}(\mathrm{C})$ and its slightly variant (Basthomi, 2006, p. 94). The rhetorical structure of the three journals only employ three sections: Introduction, Discussion, Conclusion (I-D-C). Method (M) and Result (R) are missed from the all three journals. From all these three journals, only Introduction part which is available and put clearly as the section "Introduction". Similarly, the Conclusion part is also clearly put as the section "Conclusion" or "Concluding Remark" in all the three journals. However, for the Discussion part, it is quite different. There are explicitly no "Discussion" sections on the three journals. The Discussion sections are presented 'implicitly' through the presentation of sections that discuss about the problem addressed in the RA. Thus, the discussion sections are presented through some sections that function as discussion section.

\section{Moves and Steps in Introduction of Islam Related Journals}

In term of moves placement, the data reveals that all the three journals employ some variations of moves placement compare to moves placement in Swales CARS 2004 model. This means, the move patterns found are not only the moves that fit to standard placement of moves (as stated by Swales model 2004) but also its variation.

There are six variations of moves placement (Table 1), The first move placement is the organization of moves that follow Swales CARS (2004) standard placement moves: Move 1 (M1) - Move 2 (M2) Move 3 (M3). In this type of placement, the moves are well organized from Move 1 (M1), followed with Move 2 (M2) and ended with Move 3 (M3) or its slighly variation which present the repetition of some moves. The moves are in order but some moves are repeated. The second variation is non-standard moves placement. I call it as non-standard placement since this variation employ all the three moves but the moves do not follow Swales CARS (2004) model. In this variation, the moves placement can be started with M2 or M3 then followed with the other moves. The third variation is the absence of M1. The RAs which do not have M1 is classified to this variation. Next is the absence of M2. Fifth is the absence of M3. And the last is no moves presented. Among these variants, all the three journal reveal that the the majority of moves placement in the journals follow standard placement of moves in Swales CARS (2004) model.

In terms of moves and steps in the establishment of $\mathrm{M} 2$, all the three journals tend to make topic generalization in establishing M1 by making statement about phenomena and/or followed by outlining some information. For Al-Jamiah and IJIMS, these two journals tend to establish M1 by making sentence about phenomena. Moreover, the establishments of M1 occur more consistently after outlining some information or review of concept related to the topic which is explored in sentences or paragraphs. On the other hand, JIS establish M1 by making statement about phenomena or practice 
equally. Half of the data in JIS establish M1 by making statement about phenomena and the rest is by making statement about practice and knowledge. More interestingly, in JIS, M1 is established mostly at the first paragraph or even as the first sentence of the paragraph.

Related to the type of citation that is required in this move, all three journal employ the type of citation that is categorized as non-integral citation. Non-integral citation is where the name of the researcher occurs either in parenthesis or elsewhere by supercript number or via some other device (Swales, 1990, p. 148). Interestingly, there is one unique finding that one RA quoted verses from Qur'an and included the Arabic letter. This quoatation somehow nuances more Islam sense on the RA. However, it is the one and only RA. Among the RA's analyzed, only one RA IJIMS/ 2015-3 that use that kind of quotation. This can be seen in Example 1.

Example 1

It is said in the Al- Qur'an Sura Al-Baqarah verse 197:

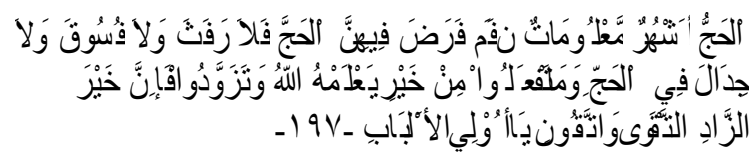

"The Hajj (pilgrimage) is (in) the well-known (lunar year) months (i.e. the 10th month, the 11th month and the first ten days of the 12th month of the Islam calendar, i.e. two months and ten days). So whoever intends to perform Hajj therein by assuming Ihram), then he should not have sexual relations (with his wife), nor commit sin, nor dispute unjustly during the Hajj. And whatever good you do, (be sure) Allah knows it. And take a provision (with you) for the journey, but the best provision is At-Taqwa (piety, righteousness, etc.). So fear Me, O men of understanding!"'2

Differently, for establishing M2,Al-Jamiah journal shows M2-S2 (presenting positive justification) as the major step used than S1A (Indicating gap). On the other hand, JIS and IJIMS use both steps (S1A and S2) equaly. However, JIS seems to be the only journal that is lack of the use of M2 compared to the other two journals. Another finding is that some articles in the three journals employ both S1A and S2. In case of the use of S1B, all three journals do not employ this step.

In establishing M3, S1 which announces the present research descriptively or purposively becomes the major step found in all the three journals. The other steps that are found in the three journals are S2- Presenting RQs, S4- Summarizing methods, S5- Announcing principal outcomes, and S7-Outlining the structure of the paper.

\section{DISCUSSION}

Regarding the macro structure of RAs in Islamic related issues journal, the findings reveal that RAs in Islamic related Issue journal published from three different journals in Indonesia do not closely follow the generic structures or the macro structures of RA which is $\operatorname{IMRD}(\mathrm{C})$. This study reveals different variant of macro struture that is by ommitting the Result (R) and Method (M) sections. Of the difference in disciplinary focus, generally, the findings of the macro structure in Islamic Related RAs support the previous findings by Mirahayuni (2002) and Rakhmawati (2013). Mirahayuni (2002, p. 30) stated that the non-native English have variations in IMRD structure which indicates a less consistent pattern than the native English RAs. Similarly, Rakhmawati (2013) argues that there might be a certain characteristic of RAs structures in journal published by Indonesian academics. Thus, the particular macro structure presented by the RAs in Islamic related journals indicates a particular characteristic of the discipline.

Safnil (2013, p. 191) stated that Indonesian RA authors and/or the journal editors might have used their Indonesian discourse style when editting and/or writing in English because that might be the only rhetorical style of academic discourse they were famililar with. On the other words, Indonesian RA authors and/or editors are still closely attached to the writing style in their native language. At the same stand, Rakhmawati (2013, p. 275) argues that the difference is partly the result of different traditions and cultures, particularly of Indonesian people, that are being considered as part of the oriental culture of East Asia, while English as from an Anglophone background.

Moreover, the findings of the macro structure in this study strengthens the reason of Swales CARS (2004) model. RAs that do not closely follow IMRD (C) structure tends to be more to non-empirical RA or conceptual RA. Hence, Swales CARS (2004) model is considered as more appropiate than the older version (Basthomi, 2006; Rakhmawati, 2013).

In terms of the placement of the moves, the majority of the RAs in this study follow the standard place- 
ment of Swales CARS (2004) model. However, among the three journals, only two journals (Al-Jamiah and IJIMS) whose RAs mostly follow the standard placement. On the other hand, the majority of moves placement in the other journal (JIS) is No M2. This finding is in line with Ahamad and Yusof's (2012) finding which shows the overall move-pattern of Islamic academic RA Introduction does not closely follow the pattern proposed by CARS model (1990). Moreover, they also found that the ommission of M2 in Introduction section becomes the second predominant movespattern in the journals. According to them, this is because of the nature of Islamic articles topic that is theoretical type which consider that M2 is unnecessary.

Additionally, the cultural factor of course also also take into aaccount that result in the strategy to address the content of each macro structures: M1-M2-M3 establishment. Hence, the establishment of moves in Islamic related issues RAs Introduction is considered as 'indirect' which can be shown from the numbers of paragraphs that are not listed in Swales CARS (2004) model. Those paragraphs mostly discuss the concepts or events related to the topic rather than the previous studies to support the argument. This affects the prospect of international publication of Indonesian RAs. As cited in Rakhmawati (2013, p. 274), lengthy explanation of some topics may bring about problems regarding the editing process and prospect writing RAs for an international audience.

Moreover, the RAs are still lack of gap which seems to be rarely established in RAs as those written by native speaker of English. On the other words, there are not strong arguments in the RAs. The niche or the gap is shown from a very polite strategy. That is by presenting positive justification which is valued as more polite than showing the 'gap'. Basthomi (2006) argues that the tendecy of being polite (of Indonesian) is because they hold up the norms of 'unggahungguh'. Hence, contrasting to the idea of other people is considered impolite and againts this norms.

In brief, RAs published by accredited journals in Indonesia has not closely fit to meet the target readers for international publication as indicated in Swales (2004) CARS model. Some points that need to be noted is related to the macro or generic structures of the RAs, the common existence of paragraphs about concept or related events and the lack of attempts to contrast with previous research. These can be considered as the characteristic of Islamic related RAs.

\section{CONCLUSIONS}

The present study deals with genre analysis of the written language particularly in the form of research article which focuses on the introduction part. This study taps on the rhetorical or generic structure of the research articles (RAs) and also deals with the rhetorical pattern of Research Articles introduction (RAI) section in accredited Islamic related journal published in Indonesia. The generic structure of the RA was analyzed based on previous findings in genre analysis conducted by Basthomi (2006), Mirahayuni (2002), and Rakhmawati (2013). The RAI was examined using Swales CARS (2004) model which consists of three moves: Move 1-Establishing a territory (citation required), Move 2 - Establishing a niche (citation is possible), Move 3 - Presenting the Present Work. Each move in the model consists of some steps that support the moves. In total, there are eleven steps as the framework for move establishment.

The findings of the study show that the rhetorical or the generic structures of the RAs in Islamic related journals published in Indonesia is not in line with the general generic structure of RAs in genre analysis (IMRD(C) and its slight variant). The generic structure in the study reveals a slight variant of IMRD(C) structure of RAs by omitting the Method and Result sections. Regarding the moves in the RAI, the findings show variants of move placement which is different from Swales CARS (2004) model. Interestingly, JIS, the only journal that show No M2 moves placement frequency of occurrence is higher than the standard move placement. The finding of the Move 2 placement points towards the findings of Ahamad and Yusof (2012) and Rakhmawati (2013). Ahamad and Yusof (2012) state that Islamic academic RA introduction tend to skip the establishment of M2. In the relation with the use of steps, the establishment of M2 is mostly done by employing S2-presenting positive justification rather than S1A which is indicating gap. This strengthens the tendency of the journals to be as positive or at the good side. On the other side, this also tends to show the tendency of being less critical in the RAs.

The conclusion of the study leads to bear some recommendations both in pedagogical and future researches. In term of pedagogical recommendations, this is significant as the RAs is a result of process. The process that include the knowledge of the writer $\mathrm{him} /$ herself, the approval from journals editors before publishing the RAs, and also the teacher/lecturers that teach students academic writing especially for English 
for Academic Purpose (EAP). In term of the future researches, this study has come with some limitation which is clearer after the research done, thus this study need confirmation from the future researches.

Firstly, the pedagogical implications is for the research article writers especially writers that write Islamic related article, journal editors, and lectures in English for Academic Purposes (EAP). For the research article writers, this will help them to have knowledge on the rhetorical convention of particular genre such as Research Article (RA) so that their writing can be accepted by the discourse community in wider context: international publication. For journal editors, this might also help them to look upon their criteria in selecting and publishing the RAs. For the lectures in EAP, this is quiet important since research article journal publication is now on demand. The lectures need to consider the knowledge or convention of rhetorical pattern of Research Article in their teaching to help the students especially those who are not from English major to be able to produce RA in English.

Secondly, the recommendation is addressed to future researches in genre analysis. To the best of my knowledge, this study has become the first study in Indonesia that examines rhetorical structure in Introduction in Islamic related journals. Moreover, the data is limited to the accredited journals by DIKTI that is being ranked as " $\mathrm{A}$ ". Hence, this is still widely open to conduct research in the same field to confirm the findings of this study. Future research can conduct similar research in other Islamic related journals which is ranked as B or by comparing between the RAs published in Indonesia and the International journals. Examing the RAs which is not acredited may also be needed to clarify the remaining issue in genre analysis.

\section{REFERENCES}

Agrawal, J. (2015). Analysis of Rhetorical Structures of Research Article Introductions. http://dx.doi.org/ 10.13140/RG2.1.3227.4009.

Ahamad, M.I \& Yusof, A.M. (2012). Genre Analysis of Islamic Academic Research Article Introductions. Social and Behavioral Sciences 66(157-168). http:/ /dx.doi.org/10.1016/j/sbspro.2012.11.257.

Anwar, K. (2010). Rhetorical Patterns of Research Articles in Language Teaching Journals (Unpublished doctoral dissertation). Universitas Negeri Malang: Malang.

Bagaric, V. (2007). Defining Communicative Competence. Metodika, 8, 94-103.
Basthomi, Y. (2006). The Rhetoric of Research Article Introductions Written in English by Indonesians, (Unpublished doctoral dissertation). Universitas Negeri Malang: Malang.

Basthomi, Y. (2006). The Rhetoric of Article Abstracts: A Sweep through the Literature and a Preliminary Study. BAHASA DAN SENI, 34(2), 174-188.

Chahal, D. (2014). Research Article Introductions in Cultural Studies: A Genre Analysis Exploration of Rhetorical Structure. Journal of Teaching English for Spedific and Academic Purposes, 2(1), 1-20.

Fazilaftar, A.M. \& Naseri, Z.S. (2014). Rhetorical Moves in Applied Linguistics Articles and their Corresponding Iranian Writer Identity. Procedia-Social and Behavioral Sciences. http://dx.doi.org/10.1016/ j.sbspro.2014.03.444.

Gecikli, M. (2013). A Genre-Analysis on the Rhetoretical Organization of English and Turkish PhD Theses in the field of English Language Teaching (Unpublished master's thesis).

Khany, R. \& Tazik, K. (2010). A Comparative Study of Introduction and Discussion sections of Sub-disciplines of Applied Linguistics Research Articles. Journal of Applied Language Studies (JALS), 1(2), 97-122.

Mirahayuni, N.K. (2002). Investigating Textual Structure in Native and Non-native English Research Articles: Strategy Differences between English and Indonesian Writers. TEFLIN Journal, 12(1), 22-57.

Rakhmawati, A. (2013). A Comparison od Indonesian and English Research Articles Written by Indonesian Academic: Integrating perspectives on Genre and Rhetorical Diversity (Unpublished doctoral dissertation). The University of New England: New South Wales.

Safnil. (2013). A Genre-Based Analysis on The Introductions of Research Articles Written by Indonesian Academics. TEFLIN Journal. http://dx/doi.org/10.15639 /teflinjournal.v24i2.180-200.

Samraj, B. (2002). Introductions in Research Articles: Variations across Disciplines. English for Specific Purposes, 2, 1-17.

Suryani, I., et al. (2014). Rhetorical Structures in Academic Research Writing by Non-Native Writers. International Journal of Higher Education. http://dx.doi. org/10.5430/ijhe.v3n1p29.

Swales, J.M. (1990). Genre Analysis: English in Academic and Research Settings. Cambridge: Cambridge University Press.

Swales, J.M. (2004). Research Genres: Exploration and Applications Cambridge: Cambridge University Press. 